\title{
PENGEMBANGAN MULTIMEDIA INTERAKTIF PENGENALAN SALAT UNTUK MENINGKATKAN ASPEK PERKEMBANGAN ANAK USIA DINI
}

\author{
Lusi Marlisa \\ Program Magister Studi Pendidikan Islam Anak Usia Dini UIN Sunan \\ Kalijaga yogyakarta \\ Lusimarlisa1@gmail.com \\ Sigit Purnama \\ Program Magister Studi Pendidikan Islam Anak Usia Dini UIN Sunan \\ Kalijaga yogyakarta \\ sigit.uinsuka@gmail.com
}

\begin{abstract}
The aims of the reaserch was (1) to know how the development of interactive multimedia in praying introduction, (2) to know the effectiveness of the use of interactive multimedia the introduction of prayer for aspects of child development in integrated isamic kindergarten Mutiara Banguntapan, Bantul Yogyakarta. The method that used in this research was Research and Development (R\&D) R\&D used for measuring the feasibility of interactive multimedia product by refering to development style of Borg \& Gall through 6 stages of development, namely (1) potential and problem, (2) data collection, (3) design product, (4) validation product, (5) revision product, (6) trials product. The result of the research showed that, (1) interactive multimedia of prayer introduction was developed based on the development prosedure Borg \& Gall. The appropriateness of product based on the validation of
\end{abstract}


media experts and material experts with an overall rating of 3.83 in the good category. So that, can be concluded that multimedia developed was suitable to use in the learning media of prayer introduction, then. (2) Application of multimedia interactive prayer performed on 15 child in the class A2 abu sufyan bin harist, by conducting experimental trials by looking at the effectiveness of the use of interactive multimedia introduction of pre and post prayers on aspects of child development. Average effectiveness before use interactive multimedia introduction prayer on aspects child development 36,54\% and Average effectiveness after use interactive multimedia introduction prayer on aspects child development $76,66 \%$ with motoric physical development $73,33 \%$, language $80 \%$, cognitive $80 \%$, social emotional 73,33\%. So it can be concluded that by using interactive multimedia the introduction of prayer to aspects of development is more effective than not using interactive multimedia recognition of prayer on aspects of development.

Keyword: Interactive Multimedia,introduction prayer, aspects Development.

\begin{abstract}
Abstrak
Penelitian ini bertujuan, (1) untuk mengetahui bagaimanakah pengembangan multimedia interaktif pengenalan salat, (2) untuk mengetahui efektifitas penggunaan multimedia interaktif pengenalan salat bagi aspek perkembangan anak di Taman Kanak-Kanak Islam Terpadu Plus Mutiara Banguntapan, Bantul Yogyakarta. Metode yang digunakan dalam penelitian ini adalah Research and Development

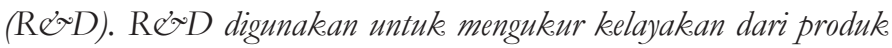
multimedia interaktif serta melakukan uji coba pada multimedia interaktif pengenalan salat, dengan mengacu pada model pengembangan Borge Gall melalui 6 tahapan pengembangan, yaitu (1). Potensi dan masalah bertujuan untuk menganalisis potensi dan masalah yang terdapat di sekolah. Kemudian melakukan analisis kebutuhan setelah mendapatkan informasi dengan melakukan observasi awal pada sekolah tersebut. (2) Pengumpulan data. Pengumpulan data yang dilakukan dari berbagai informasi yang dapat digunakan sebagai data untuk melengkapi data peneliti terkait dengan masalah penelitian, (3) Desain produk, (4) Validasi desain, (5) Revisi desain, (6) Uji coba produk. Hasil penelitian menunjukkan bahwa, (1) multimedia interaktif pengenalan salat telah dikembangkan sesuai dengan prosedur pengembangan Borge Gall. Kelayakan produk berdasarkan validasi abli media dan abli materi dengan penilaian keseluruhan rata-rata
\end{abstract}


3,83 dalam kategori baik. Sehingga, dapat disimpulkan bahwa multimedia yang dikembangkan layak untuk digunakan dalam media pembelajaran pengenalan salat, kemudian (2) penerapan multimedia interaktif pengenalan salat dilakukan pada 15 anak di kelas A2 Abu Sufyan bin Harits dengan melakukan uji coba eksperimen dengan melihat efektifitas penggunaan multimedia interaktif pengenalan salat sebelum dan sesudab terhadap aspek perkembangan anak. Rata-rata efektifitas sebelum menggunakan multimedia interaktif terhadap perkembangan anak 36,54\% dan efektifitas setelah digunakannya multimedia interaktif salat terhadap aspek perkembangan anak sebesar 76,66\% dengan perkembangan fisik motorik sebesar 73,33\%, bahasa 80\%, kognitif 80\%, dan sosial emosional 73,33\%. Jadi dapat disimpulkan bahwa dengan menggunakan multimedia interaktif pengenalan salat terhadap aspek perkembangan lebih efektif dari pada tidak menggunakan multimedia interaktif pengenalan salat terhadap aspek perkembangan.

Kata Kunci : Multimedia Interaktif, pengenalan salat, aspek. perkembangan.

\section{A. Pendahuluan}

Yang melatar belakangi peneliti dalam mengambil fokus penelitian terhadap salat dengan menggunakan multimedia interaktif disebabkan oleh beberapa hal setelah peneliti melakukan observasi awal serta wawancara dengan salah satu guru yang ada di TK IP Mutiara.

Observasi awal yang peneliti lakukan pada proses belajar mengajar di kelas pada sekolah TK IP Mutiara mendapati bahwa, dalam mengenalkan salat guru masih menggunakan media berbentuk gambar-gambar yang ditempelkan pada tembok ruangan belajar anak dan terlihat guru yang lebih sering menjadi modelling saat akan mengenalkan salat kepada anak. Kemudian saat pengamatan berlangsung, peneliti mellihat sebuah ruang sentra multimedia yang terdapat di sekolah, yang mana jika di perhatikan sebenarnya ruang sentra multimedia tersebut memiliki potensi yang cukup besar bila dioptimalisasikan dengan baik, akan tetapi kendala yang dihadapi adalah kurangnya untuk melakukan 
pengembangan serta mengoptimalisasikan sentra multimedia yang terdapat di sekolah TK IP Mutiara. ${ }^{1}$

Selanjutnya informasi yang peneliti peroleh dari hasil wawancara dengan ibu Inung sebagai salah satu guru di TK IP Mutiara mendapati bahwa dalam mengenalkan salat kepada anak didik yang baru memasuki sekolah untuk pertama kalinya mempunyai kesulitan tersendiri. Kesulitan yang dirasakan oleh guru adalah anak belum mengetahui seperti apa gerakan salat dan bagaimana bacaan dalam salat itu sendiri. Sehingga dalam mengenalkan salat kepada anak, guru yang harus menjadi model untuk mengenalkan salat pada anak, dan pada saat guru mengenalkan salat atau mengajarkan salat pada anak belum pernah menggunakan multimedia interaktif dengan mengembangkan sentra multimedia yang terdapat pada sekolah Mutiara. ${ }^{2}$ :

Berdasarkan temuan-temuan setelah dilakukannya observasi awal serta melakukan wawancara dengan salah satu guru di TK IP Mutiara, kemudian peneliti mengidentifikasi faktor-faktor yang dapat memberikan kemudahan bagi guru dalam mengenalkan salat pada anak dengan merumuskan alternative tindakan yang dapat memberikan kemudahan kepada guru yang dapat dilakukan pada proses belajar mengajar. Dalam hal ini peneliti kembali mendiskusikan alternative tindakan yang peneliti usung kepada guru dengan menggunakan multimedia interaktif dalam pemanfaatan ruang sentra multimedia yang dimiliki oleh sekolah Mutiara. Alternative yang peneliti berikan kepada guru setelah dilakukannya diskusi, mendapatkan tanggapan yang positif dari guru dengan menggunakan multimedia interaktif dalam pengenalan salat di TK IP Mutiara. Setelah di berikannya kesempatan kepada peneliti untuk dapat mengembangkan sentra multimedia yang terdapat di sekolah kemudian peneliti mencoba untuk membuat multimedia Maret 2018

${ }^{1}$ Hasil observasi lapangan di TK IP Mutiara, pada hari Rabu tanggal 21

${ }^{2}$ Hasilwawancaradi TK IP Mutiara, pada hari Rabu tanggal 21 Maret 2018 
interaktif pengenalan salat yang kemudian akan dicobakan kepada anak ketika pengenalan salat berlangsung.

Berdasarkan latar belakangyang peneliti paparkan diatas, maka permasalahan dalam penelitian ini ditekankan pada proses pengenalan salat melalui multimedia interaktif dalam bentuk animasi.Masalah utama yang ingin peneliti ungkapkan dalam penelitian ini sebagai berikut :

1. Bagaimanakah pengembangan multimedia interaktif pengenalan salat pada aspek perkembangan anak usia dini di Taman Kanak Kanak Islam Terpadu Plus Mutiara Banguntapan, Bantul Yogyakarta?

2. Bagaimanakah efektifitas penggunaan multimedia interaktif pengenalan salat bagi aspek perkembangan anak di Taman Kanak-Kanak Islam Terpadu Plus Mutiara Banguntapan, Bantul Yogyakarta?

\section{B. Metode penelitian}

Jenis peneltian ini adalah penelitian pengembangan atau yang lebih dikenal dengan R\&D (research and development). Penelitian ini bertujuan untuk mengembangkan multimedia interaktif pengenalkan salat bagi aspek perkembangan anak usia dini di Taman Kanak-Kanak Islam Terpadu Plus Mutiara Banguntapan, Bantul Yogyakarta. Dibawah ini adalah model pengembangan yang peneliti gunakan terkait dengan pengembangan multimedia interaktif yang dikembangkan, sebagai berikut:

\section{Model PengembangandanLangkahPenelitian}

Dalam pengembangan ini, model yang menjadi acuan adalah model pengembangan Borg \& Gall, Secara garis besar model pengembangan beserta langkah-langkah penelitian dan pengembangan dapat di gambarkan sebagai berikut ${ }^{3}$

\footnotetext{
${ }^{3}$ Sugiono, Metode Penelitian Pendidikan Pendekatan Kuantitatif Kualitatif dan R\&D, (Bandung: Alfabeta, 2013), h. 409.
} 
Gambar 1.1

Model ResearceAnd Development Borg \&Gall

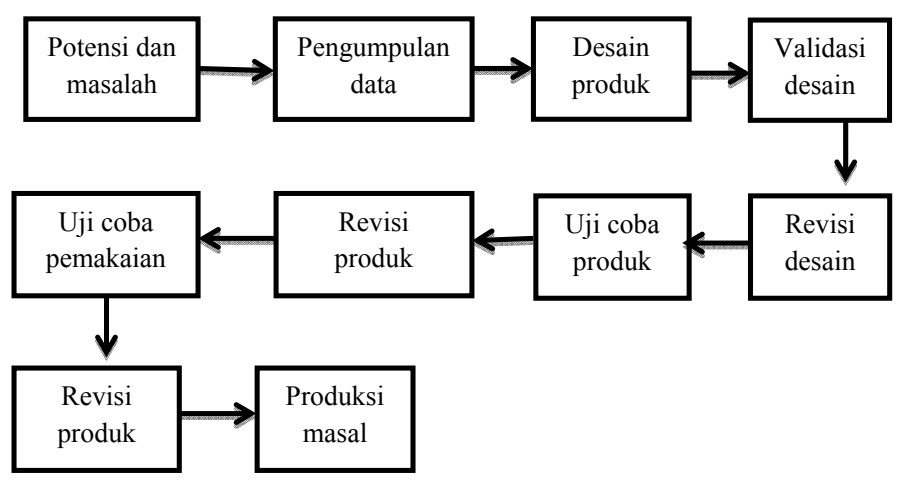

Pada gambar di atas, merupakan prosedur teknis pengembangan yang akan peneliti gunakan dalam prosedur pengembangan multimedia interaktif yang disesuaikan dengan tahapan atau prosedur dari Borg and Gall. Langkah pengembangan Borg and Gall terdapat 10 tahapan yang harus dilalui, akan tetapi dalam penggunaannya peneliti hanya menggunakan sampai pada tahapan uji coba produk setelah dilakukannya validasi pada ahli media dan ahli materi. Berikut ini merupakan gambaran umum dari tahapan Borg and Gall, sebagai berikut :

\section{a. Potensidanmasalah}

Permasalahan yang terdapat dalam mengenalkan salat pada anak di awali terlebih dahulu dengan menganalisis potensi dan masalah yang terdapat di sekolah dengan melakukan observasi awal pada proses pembelajaran dan melakukan wawancara pada guru di sekolah Mutiara. Setelah ditemukannya masalah yang dirasa perlu untuk adanya jalan keluar, kemudian peneliti melakukan analisis dan memberikan alternative kemudahan kepada guru dalam mengajarkan salat kepada anak dengan menggunakan multimedia interaktif. Setelah itu baru melakukan diskusi dengan guru setelah memberikan alternative dalam menggunakan multimedia interaktif. 


\section{b. Pengumpulan data}

Pengumpulan data yang dilakukan dari berbagai informasi yang peneliti gunakan sebagai data untuk melengkapi data peneliti terkait dengan masalah penelitian. Baik pengamatan yang dilakukan terhadap proses belajar mengajar yang terdapat pada sekolah, hasil diskusi wawancara dengan guru, kemudian melakukan pengkajian studi pustaka (kurikulum dan pedoman perangkat pembelajaran, dan yang lainnya), yang dirasakan sangat membantu dalam pengumpulan data

\section{c. Desainproduk}

Desain dan pengembangan produk yang akan peneliti gunakan diharapkan mampu mengatasi dari masalah yang ada. Desain yang akan digunakan akan dijabarkan sebagai berikut :

1. Melakukan analisis konsep animasi untuk mengenalkan sholat

2. Membuat flowchart untuk media animasi

3. Kemudian mendisain tampilan (interface) dalam membuat multimedia interaktif dalam bentuk animasi

4. Membuat sketsagambar

5. Kemudian memadukan bahan bahan yang telah terkumpul

6. Menyiapkan software yang mendukung pembuatan animasi

7. Memproduksi gambar

8. Kemudian langkah selanjutnya, setelah produk sudah divalidasi oleh ahli media dan ahli materi, selanjutnya melakukan tahapan uji coba produk

\section{d. Validasidesain}

Validasi desain yang dilakukan merupakan salah satu proses permintaan pengesahan atau persetujuan terhadap produk multimedia interaktif yang peneliti hasilkan. Validasi ini dilakukan untuk menilai sejauh mana produk multimedia interaktif yang dihasilkan dapat digunakan dalam proses pembelajaran dalam mengenalkan salat kepada anak. Validasi desain ini akan diberikan kepadaahli media dan ahli materi. 


\section{e. Revisidesain}

Revisi desain dilakukan setelah ahli media dan ahli materi melakukan validasi terkait dengan multimedia interaktif dengan memberikan penilaian serta saran-saran yang perlu mendapatkan tambahan untuk memperbaiki produk yang telah dibuat, sebelum akhirnya dapat dilakukan ujicoba di lapangan. Memperbaiki desain adalah peneliti yang akan menghasilkan produk tersebut.

\section{f. Ujicobaproduk}

Setelah selesai divalidasi dan revisi oleh tim ahli materi dengan ahli media, maka langkah selanjutnya adalah uji coba produk yang akan diuji cobakan pada kelompok yang sama sekitar 15 anak pada kelas Abu Sufyan bin Harist di TK IP Mutiara. Dalam pelaksanaannya peneliti menggunakan uji eksperiment dengan membandingkan efektifitas salat sebelum dan sesudah pemakaian multimedia interaktif pengenalan salat terhadap aspek perkembangan.

\section{Subyek Penelitian}

Subjek uji coba dalam penelitian pengembangan ini adalah anak usia 5 tahun dalam kelas A2 di TK IP Mutiara Banguntapan Bantul Yogyakarta yang berjumlah 15 peserta didik. Uji coba yang peneliti lakukan ini menggunakan eksperimen dengan melihat pengajaran sebelum dan sesudah menggunakan multimedia interakif terhadap aspek aspek perkembangan anak. Dengan menggunakan model pembelajaran bersifat Drill and Practice (Praktikdan Latihan) yang bertujuan untuk memberi kesempatan kepada peserta didik dalam melakukan praktik dan latihan untuk menguasai keterampilan dalam salat serta untuk melihat aspek perkembangan anak usia dini.

\section{Teknik pengumpulan data}

Teknik pengumpulan data merupakan langkah yang paling utama dalam penelitian, karena tujuan utama dari penelitian adalah mendapatkan data. Tanpa mengetahui teknik pengumpulan data, 
maka peneliti tidak akan mendapat data yang memenuhi standar data yang ditetapkan. Pengumpulan data dapat dilakukan dalam berbagai setting, berbagai sumber, dan bisa dilihat dengan cara teknik pengumpulan data yang dilakukan. Teknik pengumpulan data yang peneliti gunakan dengan interview (wawancara), kuesioner (angket), obeservasi (pengamatan). Pada penelitian ini peneliti menggunakan ketiga teknik tersebut dalam mengumpulkan data yang akan membantu dan menunjang proses penelitianini. ${ }^{4}$ Pengumpulan data yang peneliti gunakan terkait dengan penelitian ini adalah sebagai berikut:

\section{a. Angket}

Angket yang peneliti gunakan dalam penelitian ini adalah dengan memberikan seperangkat pertanyaan kepada ahli media dan ahli materi sebagai validator terhadap multimedia interaktif yag sedang dikembangkan untuk mengukur kelayakan dari multimedia interaktif pengenalan salat. Adapun angket yang akan diberikan kepada ahli media berisikan pertanyaan terkait dengan aspek tampilan dan aspek pemograman, sedangkan untuk ahli materi digunakan untuk memperoleh data terkait dengan aspek pembelajaran, aspek isi atau materi.

Adapun kisi-kisi atau kuesioner yang digunakan untuk mengumpulkan data sebagai uji validasi terhadap kelayakan produk ini dapat dijelaskan sebagai berikut :

1. Kisi-kisi instrumen validasi untuk ahli media terdiri dari beberapa aspek yaitu dari segi tampilan yang terdiri dari 10 indikator dan dari segi pemprograman yang terdiri dari 7 indikator, sebagai berikut :

${ }^{4}$ Sugiono, Metode Penelitian Pendidikan Pendekatan Kuantitatif Kualitatif dan R\&D, (Bandung: Alfabeta, 2013), h. 308. 
Tabel 1.1

Kisi-kisi Angket Untuk Ahli Media Aspek Tampilan dan Pemprograman

\begin{tabular}{|c|c|c|}
\hline No & Aspek & Indikator \\
\hline 1 & \multirow[t]{10}{*}{ Tampilan } & Desain slide \\
\hline 2 & & Pemilihan warna dan gambar \\
\hline 3 & & Komposisi dan kombinasi warna dalam gambar \\
\hline 4 & & Tampilan gambar \\
\hline 5 & & Penempatan gambar \\
\hline 6 & & Pemilihan background \\
\hline 7 & & Keserasian background \\
\hline 8 & & Kejelasan suara \\
\hline 9 & & Tampilan tata letak interface \\
\hline 10 & & Kemenarikan animasi \\
\hline 11 & \multirow[t]{7}{*}{ Pemprograman } & Komposisi setiap slide \\
\hline 12 & & Kualitas tampilan gambar \\
\hline 13 & & Kecepatan gambar \\
\hline 14 & & Kejelasan suara \\
\hline 15 & & Kualitas vidio \\
\hline 16 & & Kemudahan dalam penggunaan serta dalam memilih menu \\
\hline 17 & & Tingkat interaksi peserta didik dengan media \\
\hline
\end{tabular}

2. Kisi-kisi instrumen validasi untuk ahli materi terdiri dari beberapa aspek yaitu dari segi isi / materi yang terdiri dari 6 indikator dan dari segi pembelajaran yang terdiri dari 6 indikator, sebagai berikut :

Tabel 1.2

Kisi-kisi Angket Untuk Ahli Materi untuk Aspek Isi/Materi

\begin{tabular}{|c|c|c|}
\hline No & Aspek & Indikator \\
\hline 1 & \multirow[t]{6}{*}{ Isi / Materi } & Cakupan materi \\
\hline 2 & & Kebenaran isi yang disajikan \\
\hline 3 & & Kesesuaian materi dengan siswa \\
\hline 4 & & Kesesuaian gambar untuk untuk memperjelas materi \\
\hline 5 & & Kejelasan suara untuk menyampaikan materi \\
\hline 6 & & Konsistensi penyajian \\
\hline 7 & \multirow[t]{6}{*}{ Pembelajaran } & Kemudahan menggunakan media \\
\hline 8 & & Kemudahan memahami \\
\hline 9 & & Ketepatan menyajikan gambar \\
\hline 10 & & Kejelasan suara \\
\hline 11 & & Sesuai dengan tingkatan anak \\
\hline 12 & & Pemilihan strategi belajar (simulasi) \\
\hline
\end{tabular}


Untuk mengetahui kualitas atau kriteria dari produk yang peneliti kembangkan serta hasil penghitungan dari instrumen angket di atas yang didapatkan dari ahli media dan ahli materi, peneliti menggunakan skala rating dalam bentuk numerical rating scale, maka dari itu langkah untuk melakukan penghitungan pada hasil validasi ini dapat dihitung dengan menggunakan penghitungan sederhana menggunakan rumus sebagai berikut:

$$
\frac{X}{N}=\bar{x}
$$

Keterangan :

$$
\begin{aligned}
& \overline{\boldsymbol{x}}=\text { SkorRerata Yang Dicari } \\
& \mathrm{X}=\text { Jumlah Skor Gabungan } \\
& \mathrm{N}=\text { Jumlah Item Pertanyaan/ Pernyataan }
\end{aligned}
$$

Hasil analisis yang dijadikan pedoman untuk menentukan gambaran umum kriteria pada instrumen ahli media dan ahli materi dengan cara dikonsultasikan dengan tabel kriteria skor rerata variabel dan penafsiran sebagai berikut $:^{5}$

\section{Tabel 1.3}

\section{Kriteria skor rerata variabel dan penafsiran}

\begin{tabular}{|c|c|c|c|}
\hline No & Rentang Nilai & Kriteria & Penafsiran \\
\hline 1 & $4,01-5,00$ & Sangat Tinggi & Sangat Baik \\
\hline 2 & $3,01-4,00$ & Tinggi & Baik \\
\hline 3 & $2,01-3,00$ & Cukup & Cukup Baik \\
\hline 4 & $1,01-2,00$ & Rendah & Kurang Baik \\
\hline 5 & $0,01-1,00$ & Sangat Rendah & Sangat Tidak Baik \\
\hline
\end{tabular}

\section{b. Wawancara}

Wawancara yang peneliti gunakan dalam penelitian ini adalah wawancara tak terstruktur dimana peneliti tidak menggunakan rangkaian pertanyaan yang tertulis untuk melakukan wawancara, akan tetapi peneliti melakukan wawancara dengan memberikan pertnyaan terbuka dan bebas kepada guru dan kepala sekolah guna menemukan persoalan dan permasalahan serta mendapatkan

\footnotetext{
2016), h. 54.

${ }^{5}$ Imam Machali, Statistik Manajemen Pendidikan, Yogyakarta: Kaukaba,
} 
informasi langsung dari guru, dan kepala sekolah di TK IP Mutiara banguntapan bantul yogyakarta.

\section{c. Observasi}

Observasi yang dilakukan pada proses pembelajaran dalam kelas adalah dengan cara mengamati cara mengajar guru dalam kelas serta mengidentifikasi kesulitan-kesulitan guru dalam mengajarkan salat kepada anak. Setelah didapati informasi setelah dilakukan nya obeservasi pada proses pembelajaran dalam kelas kemudian peneliti memberikan alternative yang dapat mempermudah guru dalam pengajaran dalam kelas dengan menggunakan multimedia interaktif pengenalan salat.

\section{Hasil penelitian}

Hasil Penelitian ini telah dikembangkan sesuai dengan tahapan pengembangan Borg and Gall melalui 6 tahapan sampai pada tahapan uji coba, yang dilakukan kepada anak anak kelas A2 abu sufyan bin harist yang berjumlah 15 anak dengan menggunakan uji eksperimen sebelum dan sesudah menggunakan multimeida interaktif pengenalan salat terhadap aspek perkembangan anak. Adapun hasil dari validasi ahli media dan ahli materisetelah dilakukannya penghitungan secara kumulatif, dengan kategori baik sehingga layak untuk digunakan sebagai media pembelajaran setelah melakukan revisi produk yang dikembangkan sesuai dengan saran yang diberikan oleh ahli materi.

\section{Tabel 1.4}

Data Kumulatif Hasil Penilaian Ahli Media dan Ahli Materi

\begin{tabular}{|c|l|c|c|}
\hline No & \multicolumn{1}{|c|}{ Aspek Aspek Penilaian } & Rata-Rata & Kategori \\
\hline 1 & Aspek Tampilan & 38 & Baik \\
\hline 2 & Aspek Pemprograman & 27 & Baik \\
\hline 3 & Aspek Isi/Materi & 22 & Baik \\
\hline 4 & Aspek Pembelajaran & 24 & Baik \\
\cline { 1 - 2 } Jumlah & $\mathbf{1 1 1}$ & Baik \\
\cline { 1 - 2 } \\
\multicolumn{2}{|l|}{ Rata-rata } & $\mathbf{3 , 8 3}$ & \\
\hline
\end{tabular}

Dilihat secara keseluruhan gambaran hasil yang didapatkan baik dari ahli media dan ahli materi setelah mendapatkan jumlah 
nilai rata-rata dalam kategori "baik" terhadap produk yang peneliti kembangkan, sehingga hasil rata-rata dari kedudukan pada interval yang terdapat pada tabel 1.3, maka rata rata 3,83 berada pada interval 3,01-4,00 yang berarti tinggi dan mempunyai penafsiran baik.

Adapun untuk melihat tingkat efektifitas dari penggunaan multimedia interaktif pengenalan salat terhadap aspek-aspek perkembangan anak, terlebih dahulu peneliti memberikan treatment/perlakuan terhadap anak dengan tidak menggunakan multimedia interaktif pengenalan salat. Kegiatan tersebut peneliti lakukan untuk melihat kemampuan anak terhadap salat pada tahapan awal treatmen.

\section{Pre-test}

Instrumen penelitian yang digunakan untuk melihat aspek aspek perkembangan anak dengan keseluruhan 15 anak dalam pretest ini dengan menggunakan observasi dalam proses pembelajaran tanpa menggunakan multimedia interaktif pengenalan salat di TK IP Mutiara Bantul, Banguntapan. Hasil dari pengamatan yang peneliti lakukan menunjukkan bahwa, pengenalan terhadap salat yang tidak menggunakan media pembelajaran mendapati bahwa pada setiap aspek nya hanya mendapatkan nilai persentase sebagai berikut:

\section{Tabel 1.5}

Perkembangan Anak Tanpa Menggunakan Multimedia Interaktif

\begin{tabular}{|c|c|c|c|c|c|}
\hline \multirow{2}{*}{ No } & Nama anak & \multicolumn{4}{|c|}{ Aspek perkembangan yang diamati } \\
\cline { 3 - 6 } & & $\begin{array}{c}\text { Mengikuti } \\
\text { Gerakan } \\
\text { Dalam Salat } \\
(\text { FM.3.3-4.3) }\end{array}$ & $\begin{array}{c}\text { Mengikuti } \\
\text { Bacaan Dalam } \\
\text { Salat } \\
(\text { B.3.10-4.10) }\end{array}$ & $\begin{array}{c}\text { Mengenal dan } \\
\text { Mengetahui } \\
\text { Urutan Gerakan } \\
\text { Dalam Salat } \\
\text { (K.3.6-4.6) }\end{array}$ & $\begin{array}{c}\text { Tidak } \\
\text { Mengganggu } \\
\text { Kawan Ketika } \\
\text { Salat / Salat } \\
\text { Dengan Tertib } \\
\text { (SE. 2.6) }\end{array}$ \\
\hline 1 & Nindy & $* * *$ & $* * *$ & $* *$ & $* * *$ \\
\hline 2 & Andara & $* *$ & $* * *$ & $* *$ & $* * *$ \\
\hline
\end{tabular}




\begin{tabular}{|c|c|c|c|c|c|}
\hline 3 & Gina & $* *$ & $* *$ & $* *$ & $* *$ \\
\hline 4 & Billy & $* *$ & $* *$ & $* * *$ & $* *$ \\
\hline 5 & Agas & $S$ & $* *$ & $* *$ & $* *$ \\
\hline 6 & Aleta & $* * *$ & $* * *$ & $* * *$ & $* * *$ \\
\hline 7 & Faqih & $* *$ & $* *$ & $* * *$ & $* *$ \\
\hline 8 & Assya & $* *$ & $* * *$ & $* * *$ & $* * *$ \\
\hline 9 & Faiz & $* * *$ & $* *$ & $* *$ & $* *$ \\
\hline 10 & Zahran & I & $* * *$ & $* * *$ & $* *$ \\
\hline 11 & Nadia & $* *$ & $* *$ & $* *$ & $* *$ \\
\hline 12 & Askana & $* * *$ & $* *$ & $* *$ & $* *$ \\
\hline 13 & Fahri & $* * *$ & $* *$ & $* *$ & $* *$ \\
\hline 14 & Aqila & $* * *$ & $* *$ & $* * *$ & $* * *$ \\
\hline 15 & Alfan & $* *$ & $* *$ & $* *$ & $* *$ \\
\hline \multicolumn{2}{|c|}{$\begin{array}{c}\text { Jumlah siswa } \\
\text { yang tuntas } \\
\text { belajar }\end{array}$} & 6 & 5 & 6 & 4 \\
\hline & rsentase & $46,16 \%$ & $33,33 \%$ & $40 \%$ & $26,67 \%$ \\
\hline
\end{tabular}

\section{Keterangan :}

Untuk menghitung tingkat ketuntasan anak menggunakan penghitungan sebagai berikut :

\section{Jumlah Siswa Yang Tuntas Belajar $\mathbf{P}=\quad$ Jumlah Siswa

(anak yang dikatakan tuntas belajar adalah anak yang mendapat nilai bintang 3 atau 4)

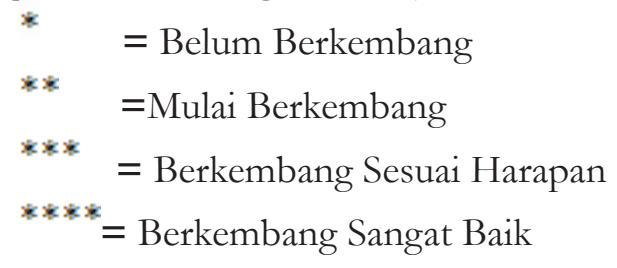


Berdasarkan pada tabel 1.5 diperoleh hasil yang sangat rendah untuk pencapaian ketuntasan belajar anak dalam pengenalan salat tanpa penggunaan multimedia pembelajaran berdasarkan pada intsrumen penilaian yang ada. Terlihat dari setiap aspek perkembangan yang diamati dari perkembangan fisik motorik terdapat persentase sekitar 46,16\%, bahasa terdapat 33,33\%, kemudian pada kognitif sebanyak 40\%, dan sosial emosional sekitar 26,67\%. Dari perolehan hasil tersebut masih sangat rendah dari yang diharapkan.

\section{Post-test}

Jika sebelumnya peneliti memberikan treatmen berupa pengenalan salat tanpa menggunakan multimedia interaktif pengenalan salat, persentase perolehan yang didapati masih sangat rendah sekali. pada kesempatan ini peneliti memberikan treatment, masih dalam kelas yang sama pada kelas abu sufyan bin harist dengan menggunakan multimedia interaktif pegenalan salat terhadap aspek aspek perkembangan anak.

Dalam setiap tahap pembelajaran yang diterapkan, masing masing berisi langkah pembelajaran yang terdiri dari penggalian konsep (ekplorasi), pengenalan konsep (invasi), penerapan konsep dengan metode drill and pactice, dan evaluasi sebagai tambahan dalam pembelajaran. Instrumen penelitian yang peneliti gunakan untuk melihat aspek aspek perkembangan anak masih sama dengan instrumen yang peneliti pakai sebelumnya. Hasil pengamatan yang peneliti lakukan menunjukkan bahwa, pengenalan terhadap salat dengan menggunakan media pembelajaran berupa multimedia interaktif mendapati bahwa pada setiap aspeknya mendapatkan nilai persentase sebagai berikut: 
Tabel 1.6

Perkembangan Anak Menggunakan Multimedia Interaktif

\begin{tabular}{|c|c|c|c|c|c|}
\hline \multirow[t]{6}{*}{ No } & \multirow[t]{6}{*}{ Nama anak } & \multicolumn{4}{|c|}{ Aspek Perkembangan yang diamati } \\
\hline & & Mengikuti & Mengikuti & Mengenal dan & Tidak \\
\hline & & Gerakan Dalam & Bacaan & Mengetahui & Mengganggu \\
\hline & & Salat & Dalam Salat & Urutan Gerakan & Kawan Ketika \\
\hline & & (FM. 3.3-4.3) & (B.3.10-4.10) & Dalam Salat & Salat / Salat \\
\hline & & & & (K.3.6-4.6) & $\begin{array}{c}\text { Dengan Tertib } \\
\text { (SE.2.6) }\end{array}$ \\
\hline 1 & Nindy & $* * *$ & $* * *$ & $* * *$ & $* * *$ \\
\hline 2 & Andara & $* * *$ & $* * *$ & ** & $* * *$ \\
\hline 3 & Gina & $* * *$ & ** & $* * *$ & ** \\
\hline 4 & Billy & *** & $* *$ & $* * *$ & $* *$ \\
\hline 5 & Agas & *** & $* * *$ & $* * *$ & $* * *$ \\
\hline 6 & Aleta & $* * *$ & $* * *$ & $* * *$ & $* * *$ \\
\hline 7 & Faqih & $* *$ & $* * *$ & ** & $* * *$ \\
\hline 8 & Assya & $* * *$ & $* * *$ & $* * *$ & $* * *$ \\
\hline 9 & Faiz & $* *$ & $* *$ & $* * *$ & $* * *$ \\
\hline 10 & Zahran & $* * *$ & $* * *$ & $* * *$ & $* * *$ \\
\hline 11 & Nadia & $* *$ & $* * *$ & $* * *$ & $* *$ \\
\hline 12 & Askana & $* * *$ & $* * *$ & ** & $* *$ \\
\hline 13 & Fahri & $* * *$ & $* * *$ & $* * *$ & $* * *$ \\
\hline 14 & Aqila & $* * *$ & $* * *$ & $* * *$ & $* * *$ \\
\hline 15 & Alfan & $* * *$ & $* * *$ & $* * *$ & $* * *$ \\
\hline $\begin{array}{l}\text { Jur } \\
\text { ya }\end{array}$ & $\begin{array}{l}\text { mlah siswa } \\
\text { ang tuntas } \\
\text { belajar }\end{array}$ & 11 & 12 & 12 & 11 \\
\hline & Persentase & $73,33 \%$ & $80 \%$ & $80 \%$ & $73,33 \%$ \\
\hline
\end{tabular}

\section{Keterangan :}

Untuk menghitung tingkat ketuntasan anak menggunakan penghitungan sebagai berikut : 


\section{Jumlah Siswa Yang Tuntas Belajar \\ $\mathbf{P}=$ \\ Jumlah Siswa}

(anak yang dikatakan tuntas belajar adalah anak yang mendapat nilai bintang 3 atau 4)

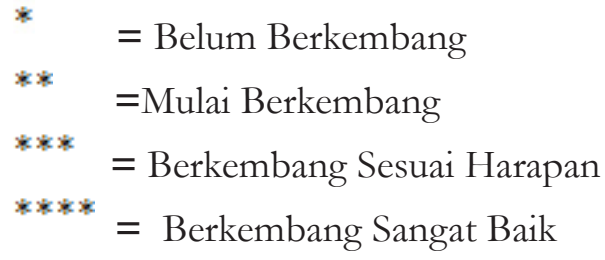

Berdasarkan pada tabel 1.6 penggunaan media pembelajaran berupa multimedia interaktif pengenalan salat terjadi peningkatan yang sangat baik dalam setiap aspek perkembangan yang diinginkan, dengan menggunakan multimedia interaktif pengenalan salat. Terlihat dari perolehan persentase keseluruhan setelah menggunakan multimedia interaktif pengenalan salat terhadap aspek perkembangan anak, seperti perkembangan fisik motorik persentase sekitar 73,33\%, bahasa terdapat $80 \%$, kemudian pada kognitif sebanyak $80 \%$, dan sosial emosional $73,33 \%$.

\section{Analisis Data}

Analisis data pada penelitian ini dilakukan dengan cara eksperimen, yaitu membandingkan efektifitas pengenalan salat pada saat tidak menggunakan multimedia interaktif dengan yang menggunakan media pembelajaran berbentuk multimedia interaktif. Treatment ini peneliti lakukan pada satu kelompok yang sama terhadap 15 jumlah keseluruhan anak pada kelas abu sufyan bin harist. Berikut ini tabel yang menunjukkan perbandingan dalam salat sebelum dan sesudah menggunakan media pembelajaran berupa multimedia interaktif pengenalan salat, sebagai berikut: 
Tabel 1.7

Sebelum dan sesudah penggunaan multimedia terhadap aspek perkembangan

\begin{tabular}{|c|c|c|}
\hline $\begin{array}{c}\text { Sebelum } \\
\text { menggunakan } \\
\text { multimedia } \\
\text { interaktif }\end{array}$ & $\begin{array}{c}\text { Aspek aspek perkembangan } \\
\text { yang diamati }\end{array}$ & $\begin{array}{c}\text { Sesudah } \\
\text { menggunakan } \\
\text { multimedia } \\
\text { interaktif }\end{array}$ \\
\hline $46,16 \%$ & $\begin{array}{c}\text { Mengikuti Gerakan Dalam Salat } \\
\text { (FM. 3.3-4.3) }\end{array}$ & $73,33 \%$ \\
\hline $33,33 \%$ & $\begin{array}{c}\text { Mengikuti Bacaan Dalam Salat } \\
\text { (B.3.10-4.10) }\end{array}$ & $80 \%$ \\
\hline $40 \%$ & $\begin{array}{c}\text { Mengenal dan Mengetahui Urutan } \\
\text { Gerakan Dalam Salat } \\
(\text { K.3.6-4.6) }\end{array}$ & $80 \%$ \\
\hline $26,67 \%$ & $\begin{array}{c}\text { Tidak Mengganggu Kawan Ketika } \\
\text { Salat / Salat Dengan Tertib } \\
\text { (SE.2.6) }\end{array}$ & $73,33 \%$ \\
\hline 36,54 & Rata- Rata & 76,66 \\
\hline
\end{tabular}

Berdasarkan pada tabel 1.7 di atas, setelah dilakukan perbandingan sebelum dan sesudah menggunakan multimedia interaktif terhadap aspek-aspek perkembangan anak menunjukkan bahwa efektifitas menggunakan multimedia interaktif pengenalan salat jauh lebih tinggi dibandingkan tidak menggunakan multimedia pengenalan salat terhadap aspek aspek perkembangan anak. Rata-rata efektifitas sebelum menggunakan multimedia interaktif terhadap perkembangan anak 36,54\% dan efektifitas setelah digunakannya multimedia interaktif salat terhadap aspek perkembangan anak sebesar 76,66\%.

Berdasarkan data di atas terlihat bahwa dengan menggunakan multimedia interaktif pengenalan salat dapat meningkatkan aspek perkembangan anak. Pada perkembangan fisik motorik sebesar $73,33 \%$, bahasa $80 \%$, kognitif $80 \%$, dan sosial emosional $73,33 \%$. Jadi dapat disimpulkan bahwa dengan menggunakan multimedia interaktif pengenalan salat terhadap aspek perkembangan lebih 
efektif dari pada tidak menggunakan multimedia interaktif pengenalan salat terhadap aspek perkembangan.

\section{Penutup}

\section{Kesimpulan}

Berdasarkan rumusan masalah dan hasil analisis data, diperoleh kesimpulan dari hasil penelitian yang menunjukkan bahwa :

a. Multimedia interaktif pengenalan salat telah dikembangkan sesuai dengan prosedur pengembangan Borg and Gall. Langkah pengembangan Borg and Gall terdapat 10 tahapan yang harus dilalui, akan tetapi dalam penggunaannya peneliti hanya menggunakan sampai pada tahapan uji coba produk setelah dilakukannya validasi pada ahli media dan ahli materi melalui 6 tahapan pengembangan, yaitu (1). Potensi dan masalah bertujuan untuk menganalisis potensi dan masalah yang terdapat di sekolah. Kemudian melakukan analisis kebutuhan setelah mendapatkan informasi dengan melakukan observasi awal pada sekolah tersebut. (2) Pengumpulan data. Pengumpulan data yang dilakukan dari berbagai informasi yang dapat digunakan sebagai data untuk melengkapi data peneliti terkait dengan masalah penelitian, (3) Desain produk, (4) Validasi desain, (5) Revisi desain, (6) Uji coba produk.

b. Kelayakan produk berdasarkan validasi ahli media dan ahli materi terhadap multimedia interaktif pengenalan salat mendapati penilaian keseluruhan rata rata 3,86 dengan ketegori baik. Dengan demikian dapat disimpulkan bahwa, media pembelajaran multimedia interaktif pengenalan salat yang di dikembangkan layak untuk digunakan dalam media pembelajaran pengenalan salat.

c. penerapan multimedia interaktif pengenalan salat dilakukan pada kelas A2 Abu Sufyan bin Harits, treatment diberikan pada satu kelompok yang sama terhadap 15 jumlah 
keseluruhan anak, dengan melakukan eksperimen, yaitu membandingkan efektifitas pengenalan salat pada saat tidak menggunakan multimedia interaktif dengan yang menggunakan media pembelajaran berbentuk multimedia interaktif pengenalan salat.

d. Berdasarkan perolehan setelah dilakukannya uji coba terhadap anak setelah melakukan perbandingan sebelum dan sesudah menggunakan multimedia interaktif terhadap aspekaspek perkembangan anak menunjukkan bahwa efektifitas menggunakan multimedia interaktif pengenalan salat jauh lebih tinggi dibandingkan tidak menggunakan multimedia pengenalan salat terhadap aspek aspek perkembangan anak. Rata-rata efektifitas sebelum menggunakan multimedia interaktif terhadap perkembangan anak 36,54\% dan efektifitas setelah digunakannya multimedia interaktif salat terhadap aspek perkembangan anak sebesar 76,66\%. Dengan menggunakan multimedia interaktif pengenalan salat dapat meningkatkan aspek perkembangan anak. Pada perkembangan fisik motorik sebesar $73,33 \%$, bahasa $80 \%$, kognitif $80 \%$, dan sosial emosional $73,33 \%$. Jadi dapat disimpulkan bahwa dengan menggunakan multimedia interaktif pengenalan salat terhadap aspek perkembangan lebih efektif dari pada tidak menggunakan multimedia interaktif pengenalan salat terhadap aspek perkembangan.

\section{Saran}

Dalam multimedia interaktif yang peneliti kembangkan tentunya tak luput dari adanya keterbatasan yang terdapat pada produk tersebut, berikut ini merupakan keterbatasan dalam multimedia interaktif pengenalan salat:

a. Jika mengacu pada gaya belajar serta kecerdasan anak yang dikemukakan oleh Howard Gardner yang terdapat di bab II, multimedia interaktif ini lebih condong pada penggunaan visual anak, sehingga multimedia interaktif pengenalan salat ini kurang cocok digunakan pada anak yang memiliki 
gaya belajar audio, kinaesthetic, karena dalam multimedia interaktif ini lebih condong kepada penggunaan visual anak dalam belajar.

b. Dalam pengenalan salat dengan menggunakan multimedia interaktif ini perlu ada yang pendampingan dalam belajar (orang dewasa baik itu guru dan orangtua), karena untuk anak usia dini belum mampu untuk mengoprasikan secara mandiri dan perlunya bimbingan dari orang dewasa disekitar.

c. Dalam multimedia interaktif yang dikembangkan ini hanya terdapat gambar anak laki laki dan tidak terdapatnya gambar anak perempuan. Hal tersebut juga dapat menyebabkan bias gender.

Setelah dipaparkannya beberapa kekurangan dalam multimedia interaktif pengenalan salat ini, diperlukannya perbaikan-perbaikan serta pengembangan lebih lanjut baik itu untuk memperbaiki dari segi tampilan, gambar, suara, dan tomboltombol yang terdapat dalam multimedia interaktif pengenalan salat ini, sehingga dapat digunakan tidak hanya untuk sampai pada saat ini saja. 


\section{DAFTAR PUSTAKA}

Abdurrahman Al-Jaziri, Kitab Shalat Fikih Empat Mą̧hab, Jakarta: PT Mizan Publika, 2010.

Abdul Aziz Muhammad Azzam dan Abdul Wahhab Sayyed Hawwas, Fiqh Ibadah, Terjm Kamran As'at Dkk, Jakarta, AMZAH: 2010.

Ahmad Susanto, Perkembangan Anak Usia Dini, Jakarta, Kencana, 2011.

Al-Quran Dan Terjemahan, Jakarta, Lautan Lestari.

Asmaji Muchtar, Fatwa-Fatwa Imam Asy-Syafi'i Masalab Ibadah, Jakarta: Amzah, 2015.

Asy-Syaikh Abdul Qadir Ar Rahbawi, Shalat Empat Mą̧ab Hanafi, Maliki, Syafi', Hambali.,Terj Nurdin Apud Sarbini, Jakarta: Akbar Media, 2018.

DadanSuryana, StimulasidanAspekPerkembanganAnak, Jakarta, Kencana, 2016.

Deni Darmawan, Teknologi Pembelajaran, Bandung, Rosdakarya, 2012.

Deni Darmawan, Pendidikan Teknologi Informasi dan Komunikasi Teori dan Aplikasi, Bandung: Rosdakarya, 2012.

Diana Mutiah, Psikologi Bermain Anak Usia Dini, Jakarta, Rawamangun, 2011.

Enna Wulandari, Penerapan Metode Praktek Untuk Meningkatkan Keterampilan Sholat Siswa Kelompok. A Paud Terpadu Jabal Rabmah Banguntapan Bantul, Skripsi, Uin-Suka, 2014.

Gifari Annisa Rohani, Pengaruh Televisi (Tv) Terbadap Aspek-Aspek Perkembangan Anak Usia 3-4 Tabun, Jurnal Pendidikan Anak Universitas Negeri Yogyakarta, Volume IV, Edisi 2, Desember 2015.

Hasan Ayub, Fikih Ibadah Panduan Lengkap Beribadah Sesuai Sunnah Rasulullah, Terj Abdurrahim, Jakarta: CLM, 2010. 
Imam Machali, Statistik Manajemen Pendidikan, Yogyakarta: Kaukaba, 2016.

Jalaludin Ahmad, Muhtar Gandaatmaja, Keluarga Muslim Dalam Masyarakat Modern, Bandung: Rosdakarya, 1994.

Lovandri Dwanda Putra, Ishartiwi, Pengembangan Multimedia Pembelajaran Interaktif Mengenal Angka Dan Huruf Untuk Anak Usia Dini,Jurnal Inovasi Teknologi Pendidikan P-Issn: 2407-0963, E-Issn: 2460-7177.

Ma'rifah Malik, Pengembangan Media Animasi Dan Dampaknya Untuk. Pembelajaran Kemabiran Kalam Kelas IV di Madrasah Ibtidaiyah Muhammadiyah Bloran, Pps Uin Sunan Kalijaga, 2014.

Mahmud Abdul Lathif Uwaidhah, Tuntunan Salat Berdasarkan Quran dan Hadits, Pagelaran: Pustaka Thariqul Izzah, 2008.

Mahsunah, Pengemabngan Metode Kisah Berbasis Multimedia

Dalam Pembelajaran Sejarah Kebudayaan Islam Di Mts

Negeri Jepon-Blora,(Pps. Uin Sunan Kalijaga, 2011.

Mansur, Pendidikan Anak Usia Dini Dalam Islam, Yogyakarta, Pustaka Pelajar, 2011.

Muhammad Bin Shalih Al-Utsaimin, Sifat Shalat Nabi Saw Dari Takbir Hingga Salam, Terj Muhtadi dan Ziyad At-Tamimi, Jakarta: Darus Sunnah, 2014.

Muhammad Fuad Abdul Baqi, Shahih Al-Lu'lu Wal Marjan (Terjemahan Lengkap Kumpulan Hadist Bukhari Muslim (Muttafaq Alaih)), Terjm. Abdul Rasyad Shiddiq, Jakarta: Akbar Media, 2013.

Muhammad Isa Bin Surah At-Tirmidzi, Sunan At-Tirmidzi Juz I, Terjm. Moh Zuhri Dkk, Semarang: Asy-Syifa', 1992.

Muhammmad Ali, Memahami Riset Perilaku dan Sosial, Bandung: Pustaka Cendikia Utama, 2011.

Muhammad Iqbal Hanafri, Syaipul Ramdhan, Kholifatun Nisa, Aplikasi Pembelajaran Interaktif Pengenalan Profesi Berbasis 
Multimedia Menggunakan Adobe Flash CS6, Jurnal Sisfotek Global, ISSN : 2088 - 1762 Vol. 7 No. 2, September 2017.

Munir, Multimedia Konsep dan Aplikasi Dalam Pendidikan, Bandung, Alfabeta, 2015.

M. BasyruddinUsman, Media Pembelajaran, Jakarta: Ciputat Press, 2002.

Permendikbud 137 Tahun 2014, Standar Nasional Pendidikan Anak. Usia Dini, 2015.

Restia Fatma Sari, Pengembangan Media Pembelajaran Aqidah Ahlak Berbasis Multimedia Interaktif Untuk Siswa MI Di Kulon Progo, Pps. Uinsunankalijaga, 2013.

Saur Tampubolon, Penelitian Tindakan Kelas Sebagai Pengembangan Profesi Pendidik dan Keilmuan, Jakarta, Erlangga, 2016.

Sugiono, Metode Penelitian Pendidikan Pendekatan Kuantitatif Kualitatif dan RひD, Bandung : Alfabeta, 2013

SuyadidanMaulidyaUlfah, Konsep Dasar Paud, Bandung, Rosdakarya, 2016.

Wijaya Kusumah dan Dedi Dwitagama, Mengenal Penelitian Tindakan Kelas, Jakarta, Indeks, 2010.

Wida Rahmawati, Arwinda Nugraheni, Farid Agung Rahmadi, Pengaruh Stimulasi Media Interaktif Terhadap Perkembangan Bahasa Anak 2-3 Tabun, Jurnal Kedokteran Diponegoro, Vol. 5, No. 4,Issn: 1873-1885 IssnOnline : 2540-8844, Oktober 2016.

Wahbah Zulaihi, Fiqih Imam Syafi'i, Jakarta: Beirut, 2008.

Yuliani Nurani Sujiono, Konsep Pendidikan Anak Usia Dini, Jakarta, Indeks, 2009. 